\title{
Graphite Foil-Incorporated PAN/Pitch/Phenolic-Derived Carbon/Carbon Composite and Preliminary Hermetic Sealing Test in Molten Fluoride Salt
}

\author{
Hsun-Yu Lin ${ }^{1, * 1}$, Kuo-Jung Lee ${ }^{2}$, Jiin-Huey Chern Lin ${ }^{1}$ and Chien-Ping Ju ${ }^{1, * 2}$ \\ ${ }^{1}$ Department of Materials Science and Engineering, National Cheng-Kung University, Tainan 70101, Taiwan, ROC \\ ${ }^{2}$ Department of Materials Science and Engineering, I-Shou University, Kaohsiung 84001, Taiwan, ROC
}

$\mathrm{C} / \mathrm{C}$ composite has been recommended for use in molten fluoride salt-cooled reactors as structural containment for the highly corrosive salts in heat exchangers, piping, pumps, etc. Despite their excellent high-temperature mechanical properties and chemical compatibility with molten fluoride salts, the inherently high porosity level of $\mathrm{C} / \mathrm{C}$ composites is one major challenge to the material for such applications. The numerous inherent and/or high temperature heat treatment-induced macrocracks and microcracks in $\mathrm{C} / \mathrm{C}$ composites are difficult to seal completely using conventional methods such as CVD or CVI. To overcome the porosity-related molten salt permeation problem, a graphite foil-incorporated PAN fiber, a pitch/phenolic resin matrix-derived C/C composite, was developed in the authors' laboratory. Experimental results showed that the $\mathrm{C} / \mathrm{C}$ composite with the graphite foil had lower density value, higher porosity value, and lower bending strength value than the $\mathrm{C} / \mathrm{C}$ composite without the graphite foil. A preliminary result of the hermetic sealing test in a molten mixture of LiF, NaF and $\mathrm{KF}$ salts ("Flinak" salt) showed that the graphite foil could effectively seal the underlying $\mathrm{C} / \mathrm{C}$ composite against permeation from high temperature molten salts. Furthermore, given appropriate process parameters, the graphite foil could remain tightly bonded to the $\mathrm{C} / \mathrm{C}$ structure during the entire fabrication process and the subsequent bending and hermetic sealing tests. [doi:10.2320/matertrans.M2017132]

(Received April 19, 2017; Accepted June 12, 2017; Published July 14, 2017)

Keywords: carbon/carbon composites, graphite foil, molten fluoride salt

\section{Introduction}

Due to their high thermal conductivity, high heat capacity, low vapor pressure, low viscosity and insensitivity to radiation, molten fluoride salts have shown great potential for use in the energy industry. Of the six nuclear reactor designs chosen for advanced research and development by the Generation IV International Forum ${ }^{1)}$, at least two are suggested to use molten fluoride salts as the primary coolant. Advantages of a molten salt reactor (MSR) include high safety, low nuclear waste, ability to use thorium as a nuclear fuel, and the potential of operating at very high temperatures (higher than $1000^{\circ} \mathrm{C}$ ) with high thermal efficiency.

Due to the high temperature and highly corrosive environment, a variety of high temperature corrosion-resistant materials, such as superalloys, ceramics and carbonaceous materials, have been proposed and tested on high temperature molten salts in the past decade or so. Nickel-based superalloy may be used at temperatures up to about $750^{\circ} \mathrm{C}$ in MSR systems, but at temperatures higher than that, the alloy strength often becomes insufficient ${ }^{2)}$. Olson et al. ${ }^{3)}$ compared the corrosion behavior of Incoloy- $800 \mathrm{H}, \mathrm{Fe}-\mathrm{Ni}-\mathrm{Cr}$ alloy and nearly-pure Ni in a molten LiF-NaF-KF ("Flinak") salt at $850^{\circ} \mathrm{C}$, wherein $\mathrm{Cr}$ was found to be dissolved in the molten salt and enhanced alloy corrosion. The authors also found that an electroplated layer of $\mathrm{Ni}$ could effectively increase the corrosion resistance of Incoloy- $800 \mathrm{H}$ and $\mathrm{Fe}-\mathrm{Ni}$ $\mathrm{Cr}$ model ternary alloy in high temperature molten salt. In the study of You et al. ${ }^{4}$, four Ni-based alloys (Haynes 263, Haynes 242, Hastelloy N and Hastelloy B3) were tested in LiF-NaF-KF molten salt at $600^{\circ} \mathrm{C}$. Their results also showed that the two alloys with lower Cr content (Hastelloy B3 and Hastelloy N) had better corrosion resistance.

\footnotetext{
${ }^{* 1}$ Graduate Student, National Cheng-Kung University

${ }^{* 2}$ Corresponding author, E-mail: cpju@mail.ncku.edu.tw
}

The corrosion behavior of a variety of ceramics in LiF$\mathrm{NaF}-\mathrm{KF}$ molten salt has also been investigated. Watanabe $e t$ $a l^{5)}$ compared the corrosion behavior of $\mathrm{AlN}, \mathrm{Y}_{2} \mathrm{O}_{3}, \mathrm{Er}_{2} \mathrm{O}_{3}$ and $\mathrm{Al}_{2} \mathrm{O}_{3}$ in LiF-NaF-KF molten salt at $600^{\circ} \mathrm{C}$ for 230 and 1010 hours. Watanabe et al. found that AIN had better corrosion resistance than the other three ceramics under consideration. Among the three oxides, $\mathrm{Y}_{2} \mathrm{O}_{3}$ exhibited relatively better corrosion resistance than the other two oxides in the molten salt. Wang ${ }^{6)}$ compared the corrosion resistance of a series of carbides, nitrides and oxides in Ar-protected LiF$\mathrm{NaF}-\mathrm{KF}$ molten salt at $850^{\circ} \mathrm{C}$ for 100 hours and concluded that carbides have better corrosion resistance than nitrides and oxides. Wang et al. further compared $\mathrm{ZrC}, \mathrm{SiC}, \mathrm{ZrC}-$ $20 \% \mathrm{SiC}, \mathrm{ZrC}-40 \% \mathrm{SiC}$ and found that $\mathrm{SiC}$ exhibited the best corrosion resistance among the four ceramics under consideration.

The use of carbonaceous materials in the nuclear power industry has a long history ${ }^{7)}$. In MSR, molten salt flows between the reactor core and the heat exchanger serve as both fuel and coolant. Due to its chemical inertness, ability to slow down fast neutrons and good irradiation resistance, graphite has been proposed as a candidate for exposure to molten salts as a moderator channel ${ }^{8-13)}$. Graphite is generally resistant to chemical attack by fluoride salts ${ }^{8,9)}$; nevertheless, nuclear grade graphite generally demonstrates relatively low mechanical strength and a relatively high level of porosity ${ }^{11,12)}$.

Carbon/Carbon $(\mathrm{C} / \mathrm{C})$ composites, due to their chemical inertness and ability to maintain high mechanical strength at high temperatures $\left(1400^{\circ} \mathrm{C} \text { or above }\right)^{14-16)}$, have also been recommended for use in VHTR (Very High Temperature Gas-Cooled Reactor) and molten fluoride salt-cooled reactors as structural containment for the highly corrosive molten fluoride salts in heat exchangers, piping, pumps, and vessels used for nuclear applications ${ }^{2,17)}$. Despite their excellent high temperature mechanical properties and chemical com- 
patibility with molten fluoride salts, their inherently high porosity level (leading to high permeability to molten salts) of $\mathrm{C} / \mathrm{C}$ composites is one major challenge to the material. Although the chemical vapor infiltration (CVI) technique is often used to densify composites, the numerous inherent and/ or high temperature heat treatment-induced macrocracks and microcracks in $\mathrm{C} / \mathrm{C}$ composites are extremely difficult to seal using this conventional method.

To help solve this porosity-related molten salt permeation problem, a graphite foil-incorporated PAN/pitch/phenolic resin-derived carbon/carbon composite was recently developed in the present authors' laboratory. Reported in this study are the process, some physical and mechanical properties, as well as a preliminary hermetic sealing test result of this material in a molten fluoride salt environment.

\section{Experimental}

A flow chart revealing the major procedures for manufacturing the graphite foil-incorporated PAN/phenolic-derived $\mathrm{C} / \mathrm{C}$ composite for the present study is given in Fig. 1. PANbased 2D woven cloths (Torayca T300- $2 \times 2$ Twill, Toray Co., Japan) and a petroleum pitch (A240, Ashland Oil Company, USA) were used for the preparation of the composite prepregs, while a resole-type phenolic resin (PF-650, Chang Chun Plastics Co. Ltd., Taiwan) was used for the subsequent densification cycles.

To prepare the PAN/pitch-based prepreg, five pieces of the PAN cloths were laid up and punch-needled (171 needles punched into the woven cloth 500 times in a $5 \mathrm{~cm} \times 5 \mathrm{~cm}$ area). The needled felt was vacuum-impregnated with the petroleum pitch at a temperature of $250-300^{\circ} \mathrm{C}$. The impregnated sample was then baked in an oven at $50^{\circ} \mathrm{C}$ for 6 hours to form the PAN/pitch-based prepreg. A piece of $5 \mathrm{~cm} \times$ $5 \mathrm{~cm}$ graphite foil approximately $250 \mu \mathrm{m}$ thick (GRAFOIL ${ }^{\circledR}$ GTJ, Graftech International Ltd., USA) was stacked on top of the PAN/pitch prepreg, followed by hot-pressing in a stainless steel mold at $120^{\circ} \mathrm{C}$ for 30 min under a pressure of $5 \mathrm{MPa}$ to form a graphite foil-C/C composite green body. The hot-pressed composite green body was post-cured in an air-circulated oven at $120^{\circ} \mathrm{C}$ for 8 hours.

Carbonization is one of the most time and energy-consuming steps in the entire fabrication process of $\mathrm{C} / \mathrm{C}$ com-

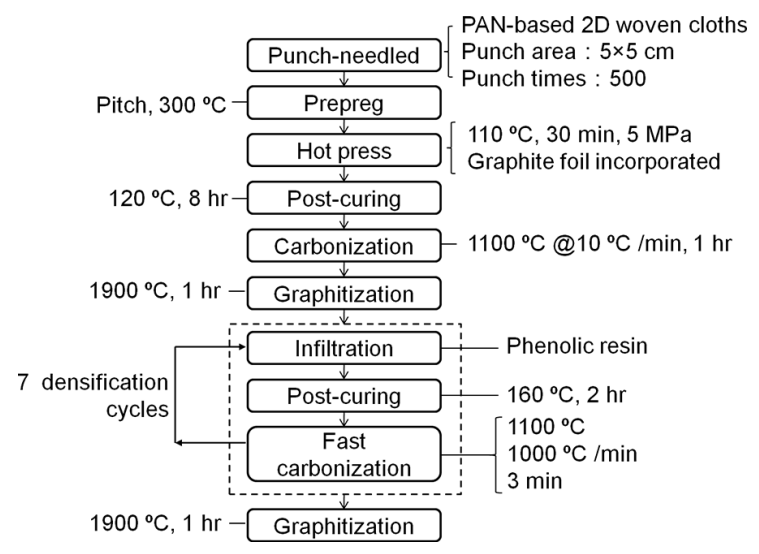

Fig. 1 Flow chart demonstrating the manufacturing process for the graphite foil-incorporated PAN/pitch/phenolic resin-derived $\mathrm{C} / \mathrm{C}$ composite. posites, especially for those densified by liquid phases. A carbonization process with an ultrahigh carbonization rate (as high as $1000^{\circ} \mathrm{C} / \mathrm{min}$ ) was developed in the present authors' laboratory ${ }^{18)}$. It was found that the composite carbonized at $1000^{\circ} \mathrm{C} / \mathrm{min}$ had a higher fracture energy and similar bending strength, compared to the composite carbonized at $1{ }^{\circ} \mathrm{C} / \mathrm{min}$. This fast carbonization process was applied to fabricate the $\mathrm{C} / \mathrm{C}$ composites for the present study.

The post-cured composite was carbonized (first carbonization) in a furnace in a nitrogen atmosphere at $1100^{\circ} \mathrm{C}$ for 1 hour at a heating rate of $10^{\circ} \mathrm{C} / \mathrm{min}$. The carbonized composite was then "graphitized" at $1900^{\circ} \mathrm{C}$ for 1 hour in a furnace with an argon atmosphere at a heating rate of $5^{\circ} \mathrm{C} / \mathrm{min}$. (Note: the term "graphitized" or "graphitization" is conveniently used throughout this text to represent heat treatment at $1900^{\circ} \mathrm{C}$ and is not an indication of a major three-dimensional ordering in a crystal structure.) After the graphitization, the porous composite was densified by vacuum impregnation of the previously discussed resole-type phenolic resin at room temperature, followed by curing at $180^{\circ} \mathrm{C}$ for 2 hours and carbonization at $1100^{\circ} \mathrm{C}$ for 1 hour at a heating rate of $1000^{\circ} \mathrm{C} / \mathrm{min}$ in a nitrogen-purged furnace ${ }^{18)}$. This impregnation/curing/carbonization cycle was repeated seven times. After the densification procedure, a second (final) graphitization treatment at $1900^{\circ} \mathrm{C}$ for $60 \mathrm{~min}$ in an argon-purged furnace was conducted.

A JEOL JSM-6510 (Japan) scanning electron microscope (SEM) equipped with an INCA X-ACT (Oxford instruments Co., England) energy dispersive spectroscopy (EDS) system was used to examine the surface morphology and chemistry of the composites. The secondary electron mode was applied under an operation voltage of $5 \mathrm{kV}$. The density and open porosity of the composite at each fabrication stage were measured using the water immersion method according to the ASTM C830 standard. The flexural strength of the $50 \mathrm{~mm} \times 8 \mathrm{~mm} \times 2 \mathrm{~mm}$ composites was measured using a three-point bending test based on the ASTM D790 standard with a span-to-depth ratio of 16. A Shimadzu AG-10kNX universal tester (Japan) was operated at a crosshead speed of $0.5 \mathrm{~mm} / \mathrm{min}$ with a support span of $32 \mathrm{~mm}$. All the bending test data were averages of at least five samples under each condition.

To conduct the Flinak immersion test (sealing test), a graphite crucible (G348 graphite, Tokai Carbon Co., Japan) with five cavities was made, as schematically shown in

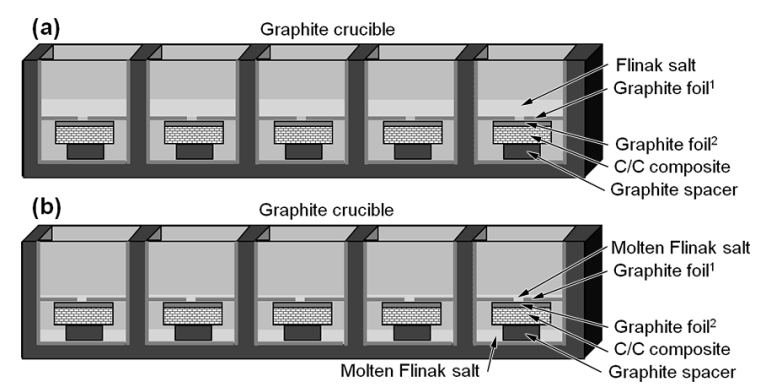

Fig. 2 Schematic figure demonstrating the molten salt immersion test. (a) before test; (b) after test. ( ${ }^{1}$ The graphite foil with a central hole separating the sample from Flinak salt. ${ }^{2}$ The graphite foil incorporated with the $\mathrm{C} / \mathrm{C}$ composite). 
Fig. 2. A piece of graphite foil with a $5 \mathrm{~mm} \times 5 \mathrm{~mm}$ central hole was used to separate each sample from the solid Flinak salt. When the solid salt reached its melting temperature $\left(454^{\circ} \mathrm{C}\right)$, the salt melted and flowed down through the central hole to attack the samples. Both $\mathrm{C} / \mathrm{C}$ samples with and without the graphite foil in contact with the molten salt at $700^{\circ} \mathrm{C}$ for 168 hours in argon-purged atmosphere were compared. The Flinak salt was prepared by dry-mixing appropriate amounts of $98.5 \%$ pure LiF (Alfa Aesar, USA), 99\% pure $\mathrm{NaF}$ (Alfa Aesar, USA) and 98.5\% pure KF (Alfa Aesar, USA) salts at a weight ratio of 29.3:11.7:59.0, followed by heating in a graphite crucible to $500^{\circ} \mathrm{C}$ for 3 hours in an argon atmosphere.

\section{Results and Discussion}

It should be noted that the term "graphite foil" used in the present study is a general term representing any graphite layer comprising natural graphite flakes or any processed graphite sheet made from natural graphite, wherein the graphite flakes or graphite sheets as well as the basal planes therein are highly aligned to be parallel to the surface of the graphite foil. For this study, a commercial product, Grafoil ${ }^{\circledR}$, was used.

The cross-sectional morphology of the as-received graphite foil is shown in Fig. 3. As shown in the SEM micrograph, the $250 \mu \mathrm{m}$ thick natural graphite flake-derived graphite foil has a very dense structure, which was the primary reason for the use of this material as a sealer to protect the underlying porous $\mathrm{C} / \mathrm{C}$ composite. Compared to the G348 graphite holders also shown in the micrograph (the graphite foil was sandwiched between two graphite plates used as a sample holder), the graphite foil appeared to be much denser than the graphite holder material.

Typical cross-sectional scanning electron micrographs of the $\mathrm{C} / \mathrm{C}$ composites manufactured in this study without and with a layer of graphite foil are shown in Figs. 4(a) and 4(b), respectively. Fiber yarns, matrix carbon and internal pores are revealed in Fig. 4(a), while a layer of graphite foil can be clearly seen in Fig. 4(b). The micrographs indicate that high temperature process-induced pores up to $200 \mu \mathrm{m}$ in size

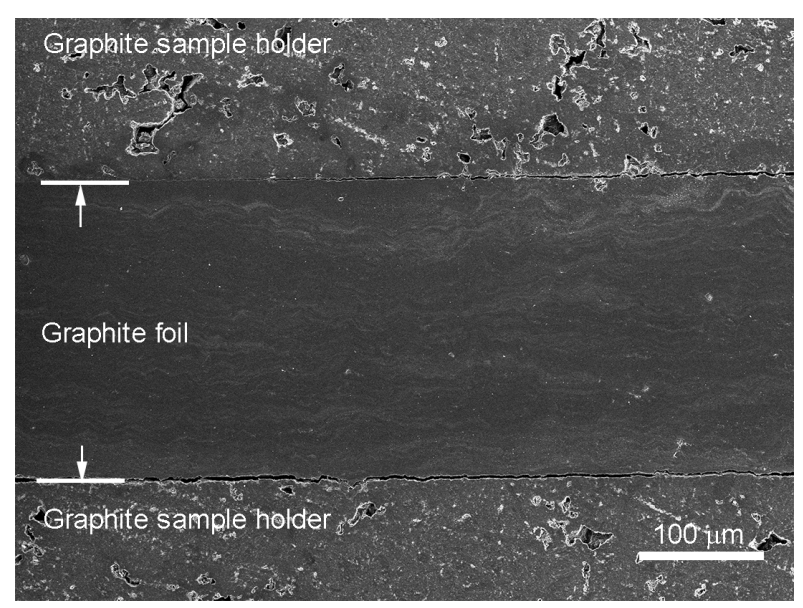

Fig. 3 Cross-sectional SEM micrograph of the graphite foil used in the study. could not be avoided after seven densification cycles. It is worth noting that the graphite foil itself was nearly fully dense in terms of structure and that the graphite foil- $\mathrm{C} / \mathrm{C}$ interface remained very tight even after a series of high temperature treatments (carbonization and graphitization).

Figure 5 and Fig. 6, respectively, show the density and porosity values of the samples in each process stage. In both figures, the sample codes for the different process stages, $\mathrm{O}$, P, C, 1G, 1D, 2D, 3D, 4D, 5D, 6D, 7D and 2G, respectively, represent the hot-pressed, post-cured, $1^{\text {st }}$ carbonized, $1^{\text {st }}$ graphitized, $1^{\text {st }}$ densified, $2^{\text {nd }}$ densified, $3^{\text {rd }}$ densified, $4^{\text {th }}$ densified, $5^{\text {th }}$ densified, $6^{\text {th }}$ densified, $7^{\text {th }}$ densified and $2^{\text {nd }}$ (final) graphitized samples. As indicated in Fig. 5 and Fig. 6, the densities of both first-carbonized composites significantly decreased, while the porosity values significantly increased. After the first graphitization, both values did not change to any significant degree. With increased densification cycles, the density values continued to increase while the porosity values continued to decrease for both composites until after the $5^{\text {th }}$ or $6^{\text {th }}$ cycle, when both values did not

\section{(a)}
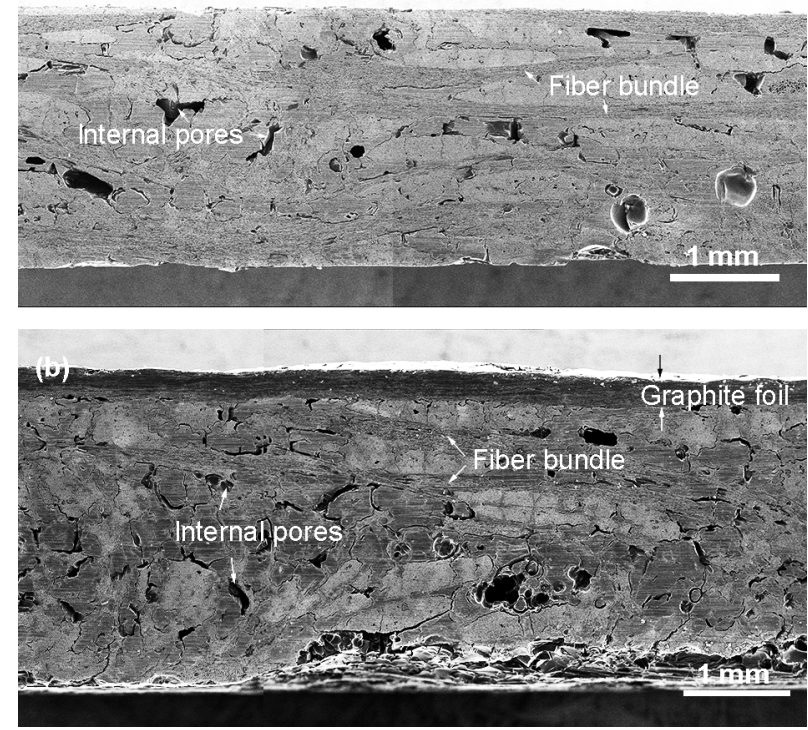

Fig. 4 Cross-sectional SEM micrographs of the PAN/pitch/phenolic resin-derived $\mathrm{C} / \mathrm{C}$ composite without graphite foil (a) and with graphite foil (b).

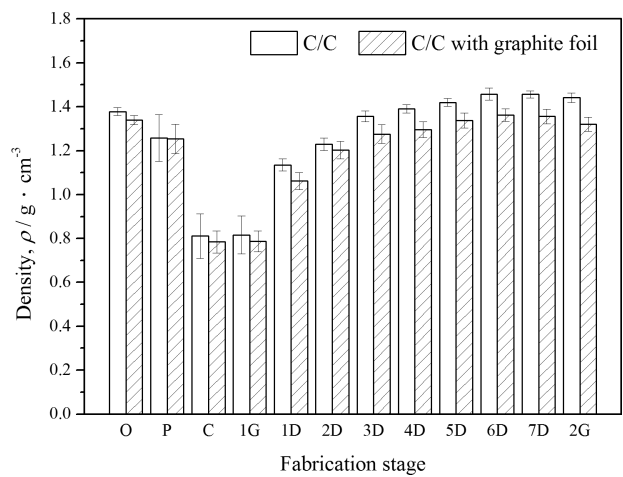

Fig. 5 Bulk density values of PAN/pitch/phenolic resin-derived $\mathrm{C} / \mathrm{C}$ composite with and without graphite foil in different process stages. 
change significantly. Furthermore, the two figures clearly indicate that, compared to the $\mathrm{C} / \mathrm{C}$ composite without graphite foil, the graphite foil-incorporated $\mathrm{C} / \mathrm{C}$ composite almost always had a lower density level $\left(1.32 \mathrm{~g} \mathrm{~cm}^{-3}\right.$ vs. $1.44 \mathrm{~g} \mathrm{~cm}^{-3}$ in average) and higher porosity level (17.2\% vs. $12.3 \%$ in average). These differences are believed to be due to the presence of the dense graphite foil, which somewhat hindered the penetration (release) of the gases produced during the processes, especially the carbonization process. Due to its lower density/higher porosity level as well as the inherently low strength of the graphite foil itself, the $\mathrm{C} / \mathrm{C}$ composite with graphite foil had an average lower bending strength $(50.1 \mathrm{MPa})$ as compared to the composite without the graphite foil (81.6 MPa).

The typical bending stress-strain profiles of the $\mathrm{C} / \mathrm{C}$ composite with and without the graphite foil are shown in Fig. 7. The composite with graphite foil typically had a lower bending modulus than that without the graphite foil due to the softness of the foil. Cross-sectional scanning electron micrographs of the $\mathrm{C} / \mathrm{C}$ composites without and with the graphite foil are shown in Fig. 8(a) and Fig. 8(b), respectively. In both micrographs, the fiber pull-out phenomenon was common. It is worth noting that, even though the composite had experienced multiple periods of carbonization and graphitization as well as a bending test, the graphite foil- $\mathrm{C} / \mathrm{C}$ interface remained very tight and without noticeable delamination even in the case of the interface adjacent to the highly-stressed fracture zone.

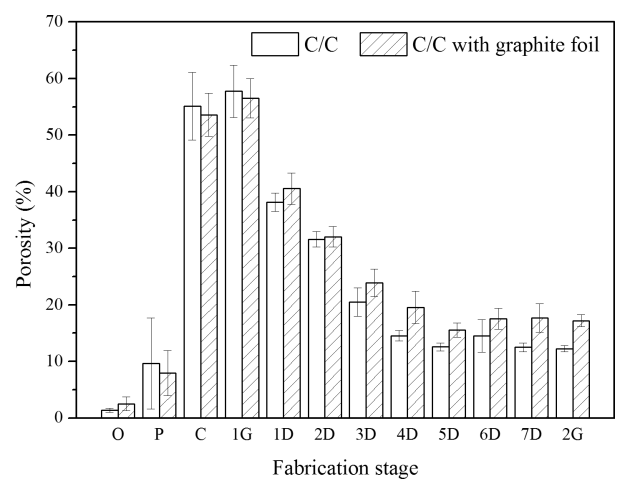

Fig. 6 Open porosity values of PAN/pitch/phenolic resin-derived $\mathrm{C} / \mathrm{C}$ composite with and without graphite foil in different process stages.

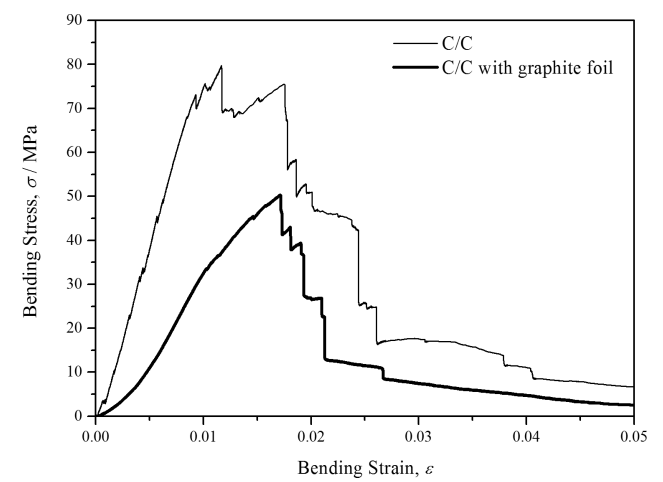

Fig. 7 Typical bending stress-stain profiles of PAN/pitch/phenolic resin-derived $\mathrm{C} / \mathrm{C}$ composite with and without graphite foil.
The sealing test of the $\mathrm{C} / \mathrm{C}$ composites with and without the graphite foil immersed in Flinak molten fluoride salt at $700^{\circ} \mathrm{C}$ for 1 week (168 hours) in an argon-purged atmosphere was investigated and compared. The cross-sectional scanning electron micrographs along with the corresponding EDS elemental $\mathrm{C}$ and $\mathrm{F}$ maps of both composites are shown in Figs. 9 and 10, respectively. It can be clearly seen in Fig. 9 that the $\mathrm{C} / \mathrm{C}$ structure without the graphite foil was severely attacked by the fluoride salt, which penetrated deeply into the interior of the composite. This result indicates that the inherently porous $\mathrm{C} / \mathrm{C}$ structure by itself is vulnerable to molten Flinak attack. On the contrary, with the protection of the graphite foil, the corrosion resistance of the composite was dramatically improved. As shown in Fig. 10, both graphite foil and the underlying $\mathrm{C} / \mathrm{C}$ structure were generally intact after exposure to the high temperature, highly corrosive environment. It is clear that, despite the inherently high porosity of $\mathrm{C} / \mathrm{C}$ composites, graphite foil can effectively seal the $\mathrm{C} / \mathrm{C}$ substrate due to its dense structure and chemical inertness. The lower strength of the $\mathrm{C} / \mathrm{C}$ composite with the graphite foil as compared to that without the graphite foil may possibly be improved by reducing the thickness of the foil in view of its excellent sealing effect against molten salt and/or by modification of the $\mathrm{C} / \mathrm{C}$ process parameters.

In the literature, coatings of carbonaceous materials have also been proposed in an attempt to avoid the infiltration of molten salts into the interior of graphite samples. Bernardet et al. ${ }^{11)}$ coated glassy carbon and pyrolytic carbon on a graphite substrate and found that pyrolytic carbon was more effective than glassy carbon in the protection of a graphite substrate against a molten salt attack. The effectiveness of using pyrolytic carbon to seal graphite from molten salts was also reported in the studies of Feng et al. ${ }^{12)}$, He et al. ${ }^{19)}$ and Song et al. ${ }^{20)}$ The comparison in terms of sealing effectiveness against molten salts between pyrolytic carbon and the graphite foil used in the present study needs further assessment.

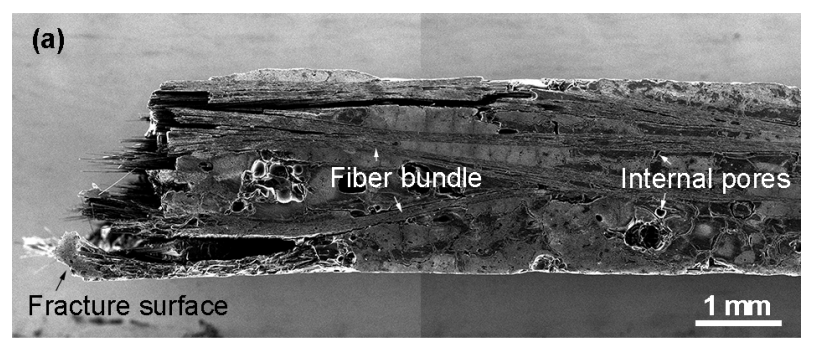

(b)

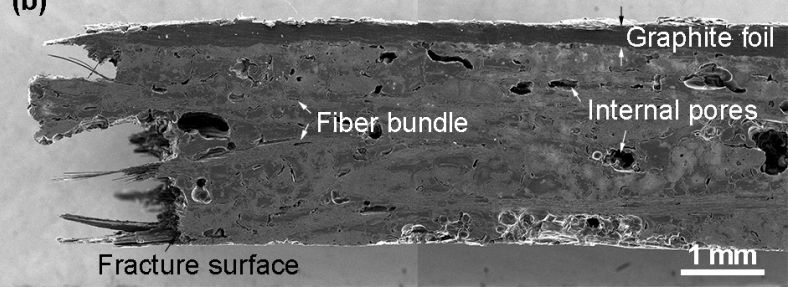

Fig. 8 Cross-sectional SEM micrographs of the bending-fractured PAN/ pitch/phenolic resin-derived $\mathrm{C} / \mathrm{C}$ composite without graphite foil (a) and with graphite foil (b). 

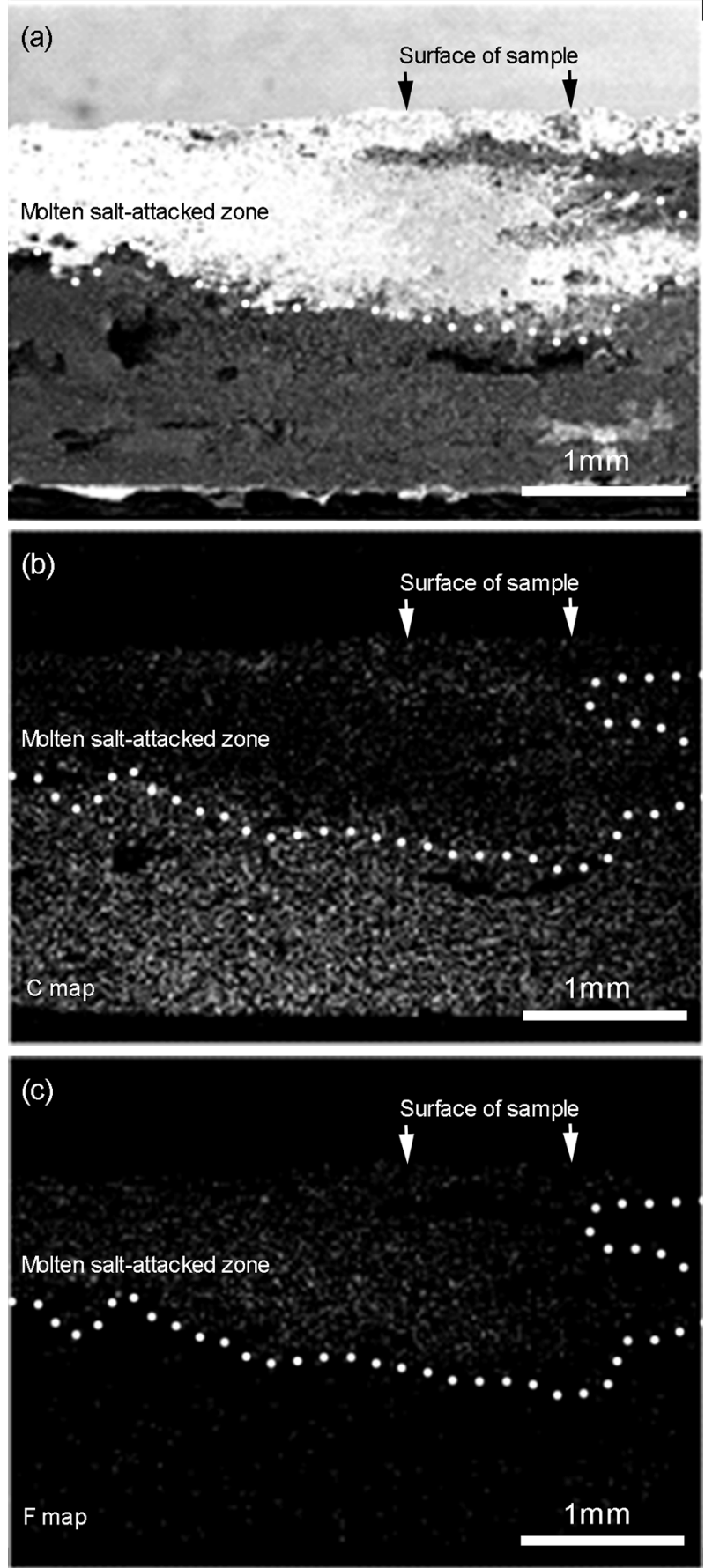

Fig. 9 Cross-sectional SEM micrograph of the PAN/pitch/phenolic resin-derived $\mathrm{C} / \mathrm{C}$ sample after Flinak immersion test (a) and EDS maps (b, c) of the same area.

\section{Conclusion}

(1) The $\mathrm{C} / \mathrm{C}$ composite with the graphite foil had a lower density, higher porosity and lower bending strength value than the $\mathrm{C} / \mathrm{C}$ composite without the graphite foil.

(2) The graphite foil can effectively seal the underlying $\mathrm{PAN} / \mathrm{pitch} /$ phenolic resin-derived $\mathrm{C} / \mathrm{C}$ composite against permeation by high temperature, highly corrosive molten fluoride salts under the current test conditions $\left(700^{\circ} \mathrm{C}\right.$ for 168 hours in argon-purged atmosphere).

(3) The graphite foil remains tightly bonded to the $\mathrm{C} / \mathrm{C}$ substrate during the entire fabrication process as well as the
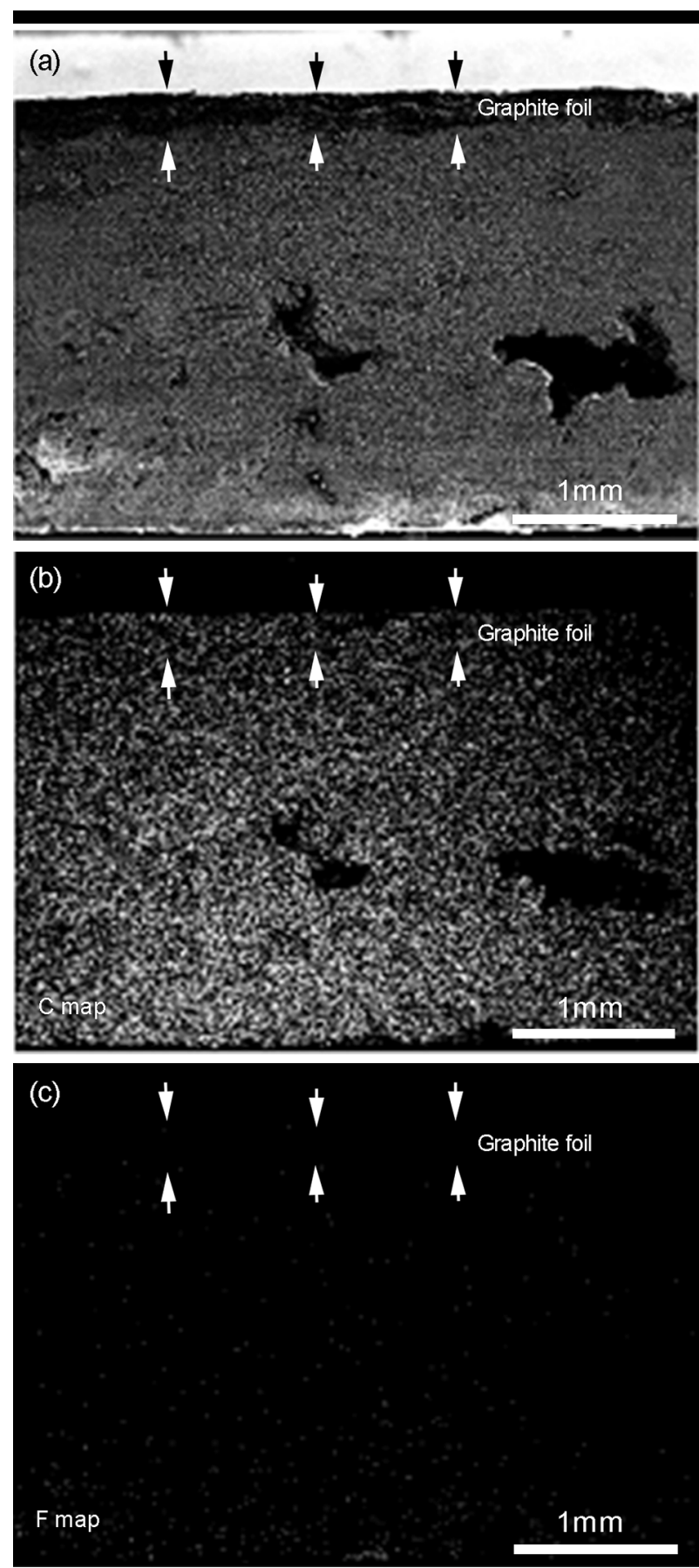

Fig. 10 Cross-sectional SEM micrograph of the graphite foil-incorporated $\mathrm{PAN} /$ pitch/phenolic resin-derived $\mathrm{C} / \mathrm{C}$ sample after Flinak immersion test (a) and EDS maps (b, c) of the same area.

subsequent bending and hermetic sealing tests.

\section{Acknowledgment}

The authors would like to acknowledge the support for this research by the Ministry of Science and Technology, Republic of China under the Research Grant No. MOST 103-2221-E-006-058-MY2.

\section{REFERENCES}

1) B. Abrams, S. Levy, D. Chapin, T. Marston, B. J. Garrick, W. Naugh- 
ton, D. Kammen and N. Todreas, U.S. DOE Nuclear Energy Research Advisory Committee and the Generation IV International Forum, 2002.

2) C. W. Forsberg, P. F. Peterson and H. Zhao, in 2004 International Congress on Advances in Nuclear Power Plants (ICAPP 04), Pittsburgh, Pennsylvania, 2004.

3) L. Olson, K. Sridharan, M. Anderson and T. Allen: J. Nucl. Mater. 411 (2011) 51-59.

4) B. C. You, in Department of Engineering and System Science, National Tsing Hua University, Hsinchu, Taiwan, ROC, 2010.

5) T. Watanabe, M. Kondo, T. Nagasaka and A. Sagara: Plasma and Fusion Research 9 (2010) 342-347.

6) Y. Wang, in College of Chemical Engineering, Xiangtan University, Hunan, China, 2013.

7) T. D. Burchell, in Carbon Materials for Advanced Technologies, ed. T. D. Burchell, Pergamon, New York, 1999, pp. 429-484.

8) R. B. Briggs, in Oak Ridge National Laboratory, 1966.

9) M. W. Rosenthal, R. B. Briggs and P. R. Kasten, Oak Ridge National Laboratory, 1969.

10) P.N. Haubenreich and J. Engel: Nucl. Technol. 8 (1970) 118-136.

11) V. Bernardet, S. Gomes, S. Delpeux, M. Dubois, K. Guérin, D. Avig- nant, G. Renaudin and L. Duclaux: J. Nucl. Mater. 384 (2009) 292 302.

12) S. Feng, L. Xu, L. Li, S. Bai, X. Yang and X. Zhou: J. Nucl. Mater. 441 (2013) 449-454.

13) J. Serp, M. Allibert, O. Beneš, S. Delpech, O. Feynberg, V. Ghetta, D. Heuer, D. Holcomb, V. Ignatiev, J.L. Kloosterman, L. Luzzi, E. Merle-Lucotte, J. Uhlír, R. Yoshioka and D. Zhimin: Prog. Nucl. Energy 77 (2014) 308-319.

14) J. D. Buckley and D. D. Edie, Carbon-Carbon Materials and Composites, Noyes Publications, 1993.

15) G. Savage, Carbon-Carbon Composites, Chapman \& Hall, 1993.

16) E. Fitzer and L. M. Manocha, Carbon Reinforcements and Carbon/ Carbon Composites, Springer-Verlag, 1998.

17) P. Yvon and F. Carré: J. Nucl. Mater. 385 (2009) 217-222.

18) H.H. Kuo, J.H.C. Lin and C.P. Ju: Carbon 43 (2005) 229-239.

19) X. He, J. Song, L. Xu, J. Tan, H. Xia, B. Zhang, Z. He, L. Gao, X. Zhou, M. Zhao, Z. Zhu and S. Bai: J. Nucl. Mater. 442 (2013) 306308.

20) J. Song, Y. Zhao, X. He, B. Zhang, L. Xu, Z. He, D. Zhang, L. Gao, H. Xia, X. Zhou, P. Huai and S. Bai: J. Nucl. Mater. 456 (2015) 33-40. 